\title{
New technology of underground structures the framework of restrained urban conditions
}

\author{
Mikhail Pleshko ${ }^{1,2 *}$, Alexander Pankratenko ${ }^{1}$, Alexey Revyakin ${ }^{2}$; Ekaterina Shchekina ${ }^{3}$, \\ and Svetlana Kholodova ${ }^{3}$ \\ ${ }^{1}$ National University of Science and Technology (MISiS), Leninskij Av., 4, Moscow, 119991, Russia, \\ ${ }^{2}$ Rostov State Transport University, Rostovskogo Strelkovogo polka sq., 2, Rostov-on-Don, 344038, \\ Russia, \\ ${ }^{3}$ Don State Technical University, pl. Gagarina, 1, Rostov-on-Don, 344022, Russia
}

\begin{abstract}
In the paper was indicated the essentiality of large-scale underground space development and high-rise construction of cities in Russia. The basic elements of transport facilities construction effective technology without traffic restriction are developed. Unlike the well-known solutions, it offers the inclusion of an advanced lining in the construction that strengthens the soil mass. The fundamental principles of methods for determining stress in advanced support and monitoring of underground construction, providing the application of pressure sensors, strain sensors and displacement sensors are considered.
\end{abstract}

\section{Introduction}

The intensive city development in the Russian Federation is characterized by a steady increase in the volumes of cargo and passenger flows, an increase in the number of cars per capita, the density of urban development, growth of high-rise construction, etc. The solution of the transport problems that accompany this process should be based on an integrated approach, which provides the development of a dedicated infrastructure for public passenger transport, city extra-personal transport; closer integration into the system of express extramodal transport of other modes of transport; construction and reconstruction of out-of-theway pedestrian crossings; organization of a priority line for urban land passenger transport traffic on highway sections; reduction in the number of junctions; promotion of public transport and related infrastructure with the active development of the underground system, light rail transport, commuter traffic, etc. It is impossible to ensure the fulfilment of these tasks without the construction of tunnel crossings and the organization of a split-level traffic of road and rail vehicles [1,2].

In contrast, the traditional schemes for the construction and reconstruction of tunnel crossings make it necessary to significantly restrict or completely stop traffic on the existing section of the road. This leads to great difficulties and significant economic losses in the organization of traffic for the period of construction or reconstruction of the site. Illustrative examples of this problem are construction works on the construction of underground

\footnotetext{
* Corresponding author: mixail-stepan@mail.ru
} 
transitions in the city of Rostov-on-Don on the st. Nagibina and st. Sholokhov, carried out in 2014 - 2015. Despite the high pace of work, the construction of crossings required the restriction of traffic for a period of up to 5 - 6 months, which caused the appearance of many kilometers of congestion on the streets under reconstruction.

In this regard, studies aimed at developing an effective technology of the construction of transport facilities without traffic restrictions, are very relevant.

In the foreign and domestic practice, technical and technological solutions for the construction of underground structures (tunnels, overpasses, underground passages, etc.) that minimize the effect on the earth's surface located above the construction sites have found application [3-5]. Indeed, in Germany, Japan, the USA and other countries protective screens are widely used. They are arranged by the technology of advanced lining. When applicating, the following methods are used: small diameter pipe ramming or soil sampling; horizontal drilling; slot dozing up to $3-4 \mathrm{~m}$ in length and $12-20 \mathrm{~cm}$ in height and over by means of scabbling or ditch-digging machine; shield driving of small diameter tunnel driving; microtunneling; soil solidification by chemical methods, jet grouting or freezing, etc. Since the late 90 -ies of the twentieth century, similar technologies began to be actively introduced in our country. Theoretical and practical aspects of their application are considered by Alikhashkin V.A.Baklashev I.V., Bulychev N.S., Golitsynsky D.M., Garber V.A., Makovsky L.V., Merkin V.E., Frolov Yu.S., Photieva N.N. and many other scientists and specialists $[3,6,7]$. Their studies, as well as practical experience in the application of methods, showed that for the construction of tunnel crossingss of short length the most convenient and universal is the scheme with application advanced lining of metal pipes [8]. At the same time, the percent of its application today does not exceed 10\%, and the main drawbacks of the known solutions are the lack of the possibility of effective monitoring and management of the soil mass deformation processes in the construction process which in some cases led to significant surface damage and destruction of the above-ground buildings and transport structures.

Thus, the main objective of the study is to improve the technology of tunnel crossing without restricting traffic by developing and reasoning for the technical solutions for monitoring and managing the stress-strain state of an underground facility.

\section{Results}

Effective building geotechnologies for the development of the underground space should be as safe as possible for the city's natural and man-made system. It should be taken into account that new objects of underground transport infrastructure are located, first of all, in the central part of the city, characterized by a high density of construction, the presence of architectural monuments and busy highways, which exclude their overlapping for a long time. In such conditions, the following basic requirements can be brought to the technologies of transport facilities construction:

- elimination of the development of excessive surface subsidence;

- exclusion of negative influence of underground objects on neighboring buildings, structures, roads and other objects of urban infrastructure;

- reduction in the volume of excavation and pumping of groundwater changing the hydrogeological situation;

- application of environmentally friendly materials and technologies for underground construction;

- Increase in technical and economic efficiency of construction $[9,10]$.

These requirements can be met when applying combined traditional and innovative building geotechnologies, the main elements of which are: 
- a technique for analyzing the stress-strain state of underground space objects in the process of construction;

- a unified system for automated management of geotechnical, engineering-geological and environmental monitoring during the construction period;

- a system of active support setting of underground structures and fixing the surrounding mass of soils on the basis of anchor systems, lining, high-strength materials and reinforcing agents;

- adaptive technology and the organization of mining operations with changing parameters of a sinking cycle, stages of opening the bottomhole, the construction of the lining;

- complex hydroprotection of underground objects with the application of new composite materials $[11,12]$.

In view of these requirements, the technology of advanced lining using a protective screen made of pipes is realized in the following sequence.

The protective screen is constructed without stopping traffic using a microtunneling complex of the Herrenknecht type. The screen is made of steel pipes $0.8-1.0 \mathrm{~m}$ in diameter, up to $35 \mathrm{~m}$ long in the required quantity (Figure 1). In contrast to the known solutions, it is proposed to incorporate active control elements and anchor systems that strengthen the soil mass in the construction of the leading edge. When constructing an underground crossing, the proposed solution provides for the construction of vertical barrels on both sides of the road in places where people go into the underground space. Then, in one of the trunks, a microtunneling complex of the Herrenknecht type is installed, and in the second guide frame for the leading support.

Firstly, the pipes of the leading support of the usual construction 1 (Figure 1) of the side walls in the direction from the bottom to the top are installed. They are connected to each other with the help of special locks. The two-section pipes with internal elements of active regulation 2 in the form of hydraulic jacks are installed the last. In parallel with the installation of the shield from the pipes, the leading anchor support 3 is installed to harden the soil massif.

Under the protection of the advanced lining, the excavation is carried out under the underground crossing. During the drilling process, complex automated monitoring is organized, the main aspects of which are discussed below. When fixing the surface subsidence, it is compensated by the activation of the elements of the leading support active regulation. If necessary, the dimensions of the bottom holes, the speed of their movement and other technological parameters are corrected.

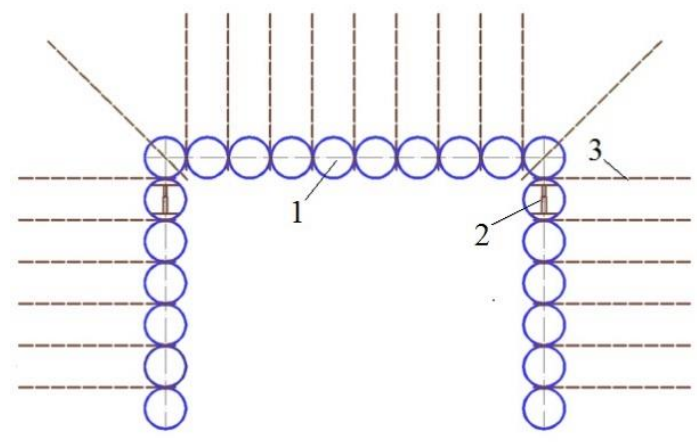

Fig. 1. The layout of the advanced lining elements.

After the sink working, it is possible to mount a membrane waterproofing from composite materials on the surface of the advanced lining and erect a constant lining of the underground crossing. In parallel, work is carried out to dismantle the microtunneling complex and to 
construct the portal parts of the crossing. At the final stage, decoration of the underground structure and improvement of the surrounding area is performed. The whole complex of works is done without restriction of traffic on the reconstructed part of the street.

In the process of erection of advanced lining and total development of an underground structure, a stress-strain state is monitored.

Based on the analysis of possible accident threats in the construction of an underground crossing, four groups of monitored parameters can be distinguished:

1. Parameters of the stress-strain state (SSS) of the constructions of the advanced lining: tension and deformation.

2. Indirect parameters of SSS lining: the pressure of the ground mass on the pipes of the advanced lining.

3. Technological parameters of the state of the object: mutual displacement of sections, translational displacement and roll of sections from the design position.

4. Environmental parameters: displacement and subsidence of the soil mass and the earth's surface.

The SSS of the advanced lining is determined by the loads of the surrounding soil and the geometrical parameters of the pipes. The design scheme of a pipe under the influence of external pressure is most conveniently represented in a cylindrical coordinate system with the origin at the center of the pipe section. In this case, the components of the stressed state in the section are radial and tangential stresses (Fig. 2).

It is known from the mechanics of a deformable solid body [13] that the radial stress on the outer surface of a cylindrical shell is numerically equal to the external pressure. The radial stress on the inner surface is determined by the internal pressure, and in this case they are equal to zero. Tangential stress in closed shell structures under the influence of external pressure is dominant and exeeds radial stress according to the $R / t$ formula. Their degree is determined by the compressive forces and bending moments arising in the considered design section:

$$
\sigma_{\theta}^{N}=\frac{N}{t l} ; \quad \sigma_{\theta}^{M}=\frac{12 M y}{t^{3} l}
$$

$N$ - compression strain; $M$ - bending moment; $t$ - the wall thickness of the pipe; $l=1 \mathrm{~m}$ single length of the pipe of the advanced lining; $y$ - the coordinate along the thickness of the pipe section with the origin at the center (see Fig. 3).

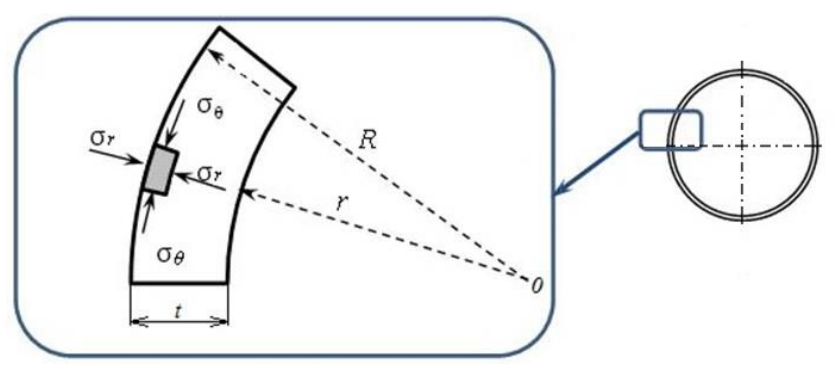

Fig. 2. Stress state in the pipe shell:

$\sigma r$ - radial stress, $\sigma \theta$ - tangential stress, $R$ - the outer radius of the pipe; $r$ - internal radius of the pipe; $t$ - the wall thickness of the pipe.

The flexural stress component reaches its maximum values at the points $y=R$ and $y=r$ (Fig. 3). At these points, the stress from bending is determined by the formula: 


$$
\sigma_{\theta \max }^{M}=\frac{12 M\left( \pm \frac{t}{2}\right)}{t^{3} l} \pm \frac{6 M}{t^{2} l} .
$$

The total maximum and minimum tangential stress taking into account the formulas (1) and (2) are:

$$
\sigma_{\theta \max / \min }^{\mathrm{tot}}=\frac{1}{t l}\left(N \pm \frac{6 M}{t}\right)
$$



a)

inner surface

b) c)

Fig. 3. Diagrams of tangential stress in the lining: a) due to the compressive force; $b$ ) due to the bending moment; $\mathrm{c}$ ) total.

Thus, the points of the control of the parameters of the SSS of the design of the advanced lining can be determined on the basis of constructive calculations for the maximum values of tangential stress in the lining. Full control of the parameters of the lead-in SSS can be made by pressure sensors, strain sensors and displacement sensors, united in a single automated monitoring system.

In Fig. 4 as an example, the typical diagram of the distribution of the maximum tangential stress in the pipes of the advanced lining and the recommended locations for the sensors of the SSS control are shown, where the maximum values of the monitored parameters are most likely to occur.

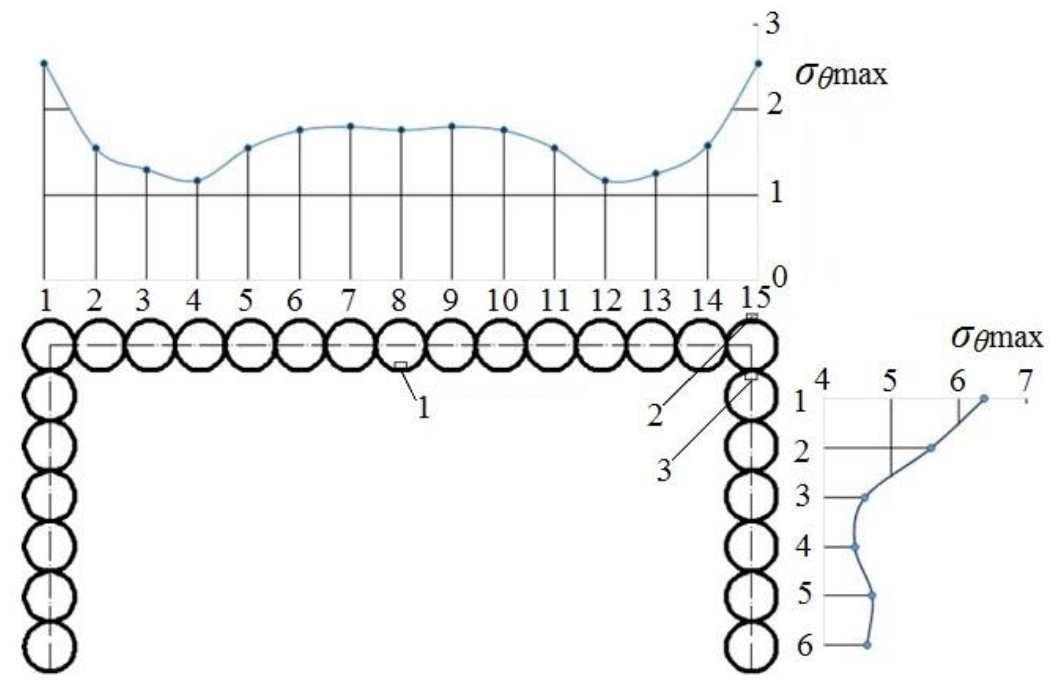

Fig. 4. Diagrams of maximum tangential stress in the advanced lining and recommended locations for the sensors of the SSS control: 1 - displacement sensors; 2 - pressure sensor; 3 - strain sensors. 


\section{Conclusions}

The introduction of the described monitoring system and elements of active regulation ensures the effective control and management of the stressed-deformed state of the advanced lining structures and allows forecasting possible natural and man-made accident threats. This ensures high safety of construction works and creates the necessary prerequisites for largescale construction of tunnel crossings in conditions of dense transport traffic and construction, as well as in complex engineering-geological conditions.

\section{References}

1. V. Korotaev, Gradostroitel'stvo. 6 (40). (2015).

2. J. Denisova, Vestnik Belgorodskogo gosudarstvennogo tehnologicheskogo universiteta im. V.G. Shuhova. 11. (2016).

3. R. Dashko, Sovremennye problemy gidrogeologii, inzhenernoj geologii i gidrogeojekologii Evrazii. Materialy Vserossijskoj konferencii s mezhdunarodnym uchastiem cjelementami nauchnoj shkoly. Nacional'nyj issledovatel'skij Tomskij politehnicheskij universitet (2015).

4. A/ Parriaux, The DEEP CITY Project: A Global Concept for a Sustainable Urban Underground Management. 11 th ACUUS International Conference, Underground Space Expanding the Frontiers. 10-13 september 2007 Athens Greece. (2007).

5. Li, H., Parriaux, A. et al., The way to plan a viable Deep City: from economic and institutional aspects. The Joint HKIE-HKIP Conference on Planning and Development of Underground Space. The Hong Kong Institution of Engineers \& The Hong Kong Institution of Planners. (2011).

6. Chang-Yu, Ou.: Deep excavation theory and practice. (London, Taylor \& Francis, 2006).

7. V. Ilyichev, et al., V sbornike: Rossijskaja arhitekturno-stroitel'naja jenciklopedija. (2008).

8. B. Kartozija, Gornyj informacionno-analiticheskij bjulleten' (nauchno-tehnicheskij zhurnal). 1. (2015).

9. E. Kulikova, Gornyj informacionno-analiticheskij bjulleten' (nauchno-tehnicheskij zhurnal). 6. (2014).

10. S. Kaloshina, Vestnik Permskogo nacional'nogo issledovatel'skogo politehnicheskogo universiteta. Stroitel'stvo i arhitektura. 7(3). (2016).

11. M. Bhatt, Journal of Siberian Federal University. Humanities \& Social Sciences. 2(6). (2013).

12. O. Semjonova Gradostroitel'stvo 3(31). (2014).

13. A. Prokopov, Web of Conferences. 106, 02001. (2017).

14. M. Rossinskaya, Life Science Journal 11 (SPEC. ISSUE 11). 43. (2014).

15. M. Pleshko, ARPN Journal of Engineering and Applied Sciences. 10(1). (2015).

16. M. Molev, ARPN Journal of Engineer and Applied Sciences. 10, no 16. (2015). 